\title{
HUBUNGAN ANTARA KARAKTERISTIK PETANI, PERSEPSI PETANI DAN TINGKAT DUKUNGAN SOSIAL EKONOMI DENGAN KEPUTUSAN PETANI MENANAM PADI VARIETAS CIHERANG DI DESA ROGOMULYO KEC. KALIWUNGU, KAB. SEMARANG
}

\author{
RELATIONSHIP AMONG FARMER CHARACTERISTICS, FARMER \\ PERCEPTION AND LEVEL OF SOCIO-ECONOMIC SUPPORT WITH \\ FARMER DECISION ON PLANTING PADDY CIHERANG VARIETY AT \\ VILLAGE ROGOMULY, KALIWUNGU DISTRICT, SEMARANG
}

\author{
Reski Ridayanti ${ }^{1)}$ dan Bayu Nuswantara ${ }^{1)}$ \\ ${ }^{1)}$ Universitas Kristen Satya Wacana \\ Email: 522014053@student.uksw.edu
}

\begin{abstract}
ABSTRAK
Tujuan penelitian untuk menganalisis hubungan karakteristik petani (tingkat pendidikan dan lama berusaha tani), persepsi petani terhadap padi varietas Ciherang, tingkat dukungan sosial dan ekonomi) dengan keputusan petani menanam padi varietas Ciherang di Desa Rogomulyo. Penelitian dilakukan AprilMei 2018. Jenis penelitian adalah deskriptif kuantitatif. Teknik penentuan sampel Random Sampling, teknik analisis data menggunakan Rank Spearman. Responden penelitian 60 petani. Pengumpulan data dengan metode survei, observasi lapangan dan wawancara terstruktur untuk petani menggunakan kuesioner. Hasil penelitian adalah persepsi petani terhadap padi varietas Ciherang, tingkat dukungan sosial, dan tingkat dukungan ekonomi memiliki hubungan positif dan signifikan dengan keputusan petani menanam padi Ciherang. Tingkat pendidikan, lama berusaha tani tidak signifikan terhadap keputusan petani menanam varietas padi Ciherang.
\end{abstract}

Kata kunci: keputusan petani, varietas Ciherang, karakteristik petani, persepsi petani, dukungan sosial-ekonomi.

\begin{abstract}
This research aims to analyze the relationship among farmer characteristics (education level and farm duration), farmer perceptions and socioeconomic factors on social support and economic support) with the decision of farmers to plant Ciherang Variety at Rogomulyo Village. This research was conducted in April-May 2018. The type of research is quantitative descriptive with Random Sampling. Data analysis techniques using Rank Spearman. Respondents were 60 farmers. Data collection was obtained using survey methods, field observations, and structured interviews for farmers using questionnaires. The results of the study was farmers' perceptions of ciherang rice, the level of social support, the level of economic support had a positive and significant relationship with the decision of farmers to plant Ciherang Variety.
\end{abstract}

Keywords: farmer's decision, Ciherang variety, farmer's characteristics, farmer's perception, socio-economic support 


\section{PENDAHULUAN}

Komoditi tanaman pangan yang banyak diusahakan petani sebagai penyuplai pangan nasional adalah tanaman padi. Padi merupakan salah satu bahan pangan nasional yang telah menjadi makanan pokok sebagian besar penduduk Indonesia (Jayanti, 2011).

Beberapa kebijakan pokok pemerintah dalam pembangunan pertanian yang terkait langsung dengan benih meliputi, peningkatan produksi untuk mencapai swasembada dan substitusi impor, pengembangan agroindustri, dan penerapan kewajiban sertifikasi untuk semua benih varietas unggul yang diperdagangkan. Menurut Nugraha (1996), penggunaan varietas benih unggul merupakan komponen utama dalam meningkatkan suatu produksi.

Menurut Menteri Pertanian (2011), varietas padi unggul merupakan varietas yang bisa berkali-kali ditanam dengan perlakuan yang baik. Hasil dari panen varietas padi unggul bisa dijadikan benih kembali. Varietas padi unggul terdiri dari Ciherang, IR64, Mekongga, Cimelati, Cibogo,
Cisadane, Situ Patenggang, Cigeulis, Ciliwung,

$$
\text { Yang melatar belakangi }
$$
keputusan petani untuk menanam suatu varietas di latar belakangi oleh berbagai hal di antaranya karakteristik petani, persepsi petani, faktor sosial ekonomi petani.

Menurut Robbins (2002), faktor sosial merupakan salah satu yang dapat mempengaruhi keputusan seseorang dalam melakukan pengambilan keputusan lingkungan sosial di kenal lingkungan keluarga dan juga tetangga anggota kelompok tani juga merupakan salah satu lingkungan sosial mereka, sedangkan faktor ekonomi merupakan salah satu yang mempengaruhi secara signifikan terhadap keputusan.

Menurut Rogers (1983), menyatakan umur, pendidikan, kepribadian, dan perilaku komunikasi (partisipasi sosial, kosmopolitan, paparan media massa, dan paparan saluran komunikasi antar pribadi), memiliki hubungan signifikan dengan pengambilan keputusan petani. di mana hal tersebut merupakan karakteristik petani. Roswita (2003) menyatakan bahwa karakteristik petani, baik 
internal maupun eksternal memiliki hubungan nyata dengan tahapan proses keputusan adopsi inovasi pengendalian hama dan penyakit tanaman agen hayati dengan tingkat keeratan yang berbeda-beda. Karakteristik internal petani berhubungan sangat nyata dengan hampir semua tahapan proses keputusan adopsi inovasi hayati, kecuali pengalaman berusaha tani dan luas lahan tidak menunjukan hubungan nyata dengan tahapan proses keputusan adopsi inovasi hayati.

Menurut data Badan Pusat Statistik Provinsi Jawa Tengah, Kabupaten Semarang merupakan salah satu daerah yang membudidayakan komoditas padi dengan total produksi pada tahun 2013 hingga 2015 sebesar 658.665 Ton, dengan kontribusi produksi yaitu $2 \%$ dari total produksi padi di Jawa Tengah. dan Kecamatan Kaliwungu salah satu Kecamatan yang berada di Kabupaten Semarang dengan luas wilayah 2.995,01 Ha. Luas wilayah sawah adalah $1.108,75$ Ha, luas wilayah bukan sawah adalah 778,71 Ha dan luas wilayah bukan pertanian adalah 1.107,55 Ha. Di mana kecamatan Kaliwungu sendiri memiliki 11 desa dimana Desa Rogomulyo merupakan daerah dengan penggunaan lahan sawah tertinggi yaitu 209,44 Ha.

Penelitian ini bertujuan untuk mengetahui hubungan antara karakteristik petani, persepsi petani dan faktor sosial ekonomi dengan keputusan petani menanam padi varietas Ciherang

\section{METODE PENELITIAN}

Penelitian ini dilaksanakan pada bulan April 2018 - Mei 2018 di Desa Rogomulyo Kecamatan Kaliwungu Kabupaten Semarang, dengan pertimbangan Desa Rogomulyo merupakan salah satu daerah penghasil padi yang sangat potensial dan cukup maju di wilayah Kecamatan Kaliwungu. Jenis penelitian ini adalah penelitian deskriptif kuantitatif. Teknik pengambilan sampel yang dipakai yaitu Simple Random Sampling. Dalam penelitian ini, diketahui bahwa jumlah populasi petani padi varietas Ciherang di Desa Rogomulyo Kecamatan Kaliwungu Kabupaten Semarang adalah 211. Dengan demikian kerangka sampling 
yang kemudian di pilih secara acak dari kerangka sampling tersebut sebanyak 60 responden. Menurut Sugiyono (2012), populasi adalah wilayah generalisasi yang terdiri atas objek/subjek yang mempunyai kualitas dan karakteristik tertentu yang di tetapkan oleh peneliti untuk dipelajari dan ditarik kesimpulanya. Misalnya bila dalam penelitian akan melakukan analisis dengan (korelasi atau regresi ganda) maka jumlah anggota sampel minimal 10 kali dari jumlah variabel yang diteliti.

Teknik pengumpulan data diperoleh menggunakan metode survei, observasi lapang dan wawancara terstruktur kepada petani menggunakan kuesioner .tingkat pendidikan, lama berusaha tani, persepsi petani terhadap padi Ciherang, tingkat dukungan sosial, dan tingkat dukungan ekonomi. menggunakan skala pengukuran (skor). Teknik analisis data menggunakan Menurut Sugiyono (2011), uji validitas merupakan salah satu usaha penting yang harus dilakukan guna mengukur kevalidan dari instrumen.

- Apabila r-hitung > r-tabel dengan df $=\mathrm{n}-2$, maka kesimpulannya kuesioner tersebut valid
- Apabila r-hitung < r-table dengan df $=$ n-2, maka kesimpulannya kuesioner tersebut tidak valid

Keterangan:

$\mathrm{n}=$ jumlah sampel

$\mathrm{df}=0,10$

Rumus yang digunakan:

$\mathrm{r}_{\mathrm{xy}}=\frac{N z X Y-(z X)(z Y)}{\left.\sqrt{\left[N\left(z X^{2}\right)-(z X)^{2} Y\left(N\left(z Y^{2}\right)\right.\right.}-(z Y)^{2}\right)}$

Uji Reliabilitas Kriteria instrumen penelitian menurut Siregar (2012) dikatakan reliabel, bila koefisien reliabilitasnya $\left(\mathrm{r}_{11}\right)>0,6$. Adapun rumus yang digunakan adalah rumus alpha cronbach,

Uji korelasi Rank spearman untuk melihat hubungan dan tingkat variabel penting karena dengan mengetahui tingkat hubungan yang ada.

$$
r_{s}=1-\frac{6 \sum d i^{2}}{n\left(n^{2}-1\right)}
$$

Keterangan:

$$
\begin{aligned}
\mathrm{r}_{\mathrm{s}}= & \text { nilai Koefisien Korelasi } \\
& \text { Spearman }
\end{aligned}
$$

$\mathrm{d}^{2}=$ Nilai selisih setiap pasangan rank

$\mathrm{n}=$ Jumlah pasangan data $(5<\mathrm{n}<$ 30) 
dengan:

$n=$ banyaknya pasangan data $(X, Y)$.

$D i=$ selisih peringkat $x i$ dan

peringkat $y i$ pada pasangan data

$(x i, y i)$,

\section{HASIL PEMBAHASAN}

Hasil Analisis Hubungan Karakteristik $\left(\mathbf{X}_{1}, \mathbf{X}_{2}\right)$ Persepsi Petani $\left(\mathbf{X}_{3}\right)$ dan Sosial Ekonomi $\left(\mathrm{X}_{4}, \mathrm{X}_{5}\right)$ Dengan Keputusan Petani $(\mathrm{Y})$

Tabel 1: Hubungan Karakteristik $\left(\mathrm{X}_{1}, \mathrm{X}_{2}\right)$ Persepsi Petani $\left(\mathrm{X}_{3}\right)$ dan Sosial Ekonomi $\left(\mathrm{X}_{4}, \mathrm{X}_{5}\right)$ dengan Keputusan Petani (Y).

\begin{tabular}{cccccc}
\hline No & Variabel & $\begin{array}{c}\text { Koefisien } \\
\text { korelasi }(\mathbf{r s})\end{array}$ & Signifikan $(\boldsymbol{\alpha})$ & $\begin{array}{c}\text { Keeratan } \\
\text { Hubungan }\end{array}$ & Keterangan \\
\hline 1 & $\mathrm{X} 1$ & $-0,213$ & 0,102 & Sangat rendah & Tidak Signifikan \\
\hline 2 & $\mathrm{X} 2$ & $-0,234$ & 0,071 & Sangat rendah & Tidak Signifikan \\
\hline 3 & $\mathrm{X} 3$ & $0,531^{* *}$ & 0,000 & Sedang & Signifikan \\
\hline 4 & $\mathrm{X} 4$ & $0,689^{* *}$ & 0,000 & Kuat & Signifikan \\
\hline 5 & $\mathrm{X} 5$ & $0,654^{* *}$ & 0,000 & Kuat & Signifikan \\
\hline
\end{tabular}

\section{Hubungan Tingkat Pendidikan $\left(\mathrm{X}_{1}\right)$ Dengan Keputusan petani (Y)}

Berdasarkan Tabel 1 dapat dilihat nilai koefisien korelasi antar variabel tingkat pendidikan dengan keputusan petani sebesar $-0,213$ dengan tanda negatif dan tidak signifikan pada tingkat kepercayaan 95\%. Hal tersebut menunjukan bahwa variabel tingkat pendidikan tidak berkorelasi dan signifikan terhadap keputusan petani. Hal tersebut menunjukan bahwa tingkat pendidikan tidak memiliki hubungan yang positif serta tingkat hubungan sangat rendah dengan keputusan petani, di mana koefisien variabel tingkat pendidikan berada pada interval $0,00-0,19$ sesuai dengan interpretasi kuatnya hubungan korelasi menurut Sugiyono (2014).

Berdasarkan hasil jawaban responden yang diwawancarai menggunakan kuesioner menunjukkan bahwa tingkat pendidikan tidak berhubungan secara signifikan, karena sebagian besar petani di Desa Rogomulya di dominasi lulusan SD jika mengambil keputusan bukan berdasarkan kepintaran atau tingkatan sekolah tetapi, petani lebih melihat dari lingkungan sekitarnya atau hasil yang sudah di lihatnya secara langsung jika petani merasa cocok petani akan 
memutuskan jenis varietas apa yang akan ditanam.

\section{Hubungan Lama Berusaha Tani} $\left(\mathrm{X}_{2}\right)$ dengan Keputusan Petani (Y)

\section{Berdasarkan Tabel 1 dapat} dilihat nilai koefisien korelasi antar variabel lama berusaha tani dengan keputusan petani sebesar -0,234 dengan tanda negatif tidak signifikan pada tingkat kepercayaan 95\%. Angka oefisien tersebut juga menunjukkan tingkat hubungan sangat rendah dengan keputusan petani, di mana koefisien variabel tingkat pendidikan berada pada interval $0,00-0,19$ sesuai dengan interpretasi kuatnya hubungan korelasi menurut Sugiyono (2014). Berdasarkan hasil analisis tersebut bahwa faktor lama berusahatani terbukti tidak memiliki kaitan dengan keputusan petani.

Tidak adanya kaitan yang signifikan antara pengalaman dan keputusan diduga karena baik petani yang mengadopsi memiliki sebaran yang hampir sama pada setiap kategori umur, dan lama berusaha tani. Dengan demikian pengalaman tidak berhubungan secara signifikan dengan keputusan petani Karena, sebagian besar petani lebih merujuk ke sosial atau lingkungan sekitarnya di bandingkan menurut pengalaman berusaha tani mereka.

\section{Hubungan Persepsi Petani terhadap Padi Ciherang $\left(\mathbf{X}_{3}\right)$ dengan Keputusan Petani (Y)}

Berdasarkan Tabel 1. dapat dilihat bahwa nilai koefisien korelasi antara variabel persepsi petani terhadap padi Ciherang dengan keputusan petani sebesar 0,531 dengan tanda positif dan signifikan pada tingkat kepercayaan 95\%. Hasil analisis tersebut menunjukan bahwa persepsi petani terhadap padi Ciherang memiliki hubungan yang positif serta tingkat hubungan sedang dengan keputusan petani, di mana koefisien variabel persepsi petani terhadap padi Ciherang berada pada interval 0,40 0,59 sesuai dengan interpretasi kuatnya hubungan korelasi menurut Sugiyono (2014).

Hasil penelitian tersebut sesuai dengan pendapat Thoha (1996), yang mengemukakan bahwa persepsi adalah proses kognitif yang di alami setiap orang dalam memahami informasi tentang lingkunganya lewat pengelihatan pendengaran dan penghayatan, Proses pemahaman 
informasi ini terjadi melalui interaksi komunikasi maka secara langsung masyarakat akan memiliki pandangan ataupun pendapat yang berbeda-beda oleh masing-masing individu.

\section{Hubungan Tingkat Dukungan sosial $\left(\mathrm{X}_{4}\right)$ dengan Keputusan Petani (Y)}

Berdasarkan Tabel 1 dapat di lihat bahwa nilai koefisien korelasi antara tingkat dukungan sosial dengan keputusan petani sebesar 0,423 dengan tanda positif dan signifikan pada taraf kepercayaan 95\%. Hal tersebut menunjukan bahwa tingkat dukungan sosial memiliki hubungan yang positif serta tingkat hubungan yang kuat dengan keputusan petani, di mana koefisien variabel tingkat dukungan sosial berada pada interval $0,60-0,79$ sesuai dengan interpretasi kuatnya hubungan korelasi menurut Sugiyono (2014).

Hasil penelitian tersebut sesuai dengan pendapat Rizka (2015) dan Susanti (2008) yang menyatakan dukungan sosial terbukti berhubungan nyata, hal ini di duga karena mendapat dukungan sosial yang tinggi terutama dukungan dari penyuluh dan dukungan yang berasal dari dukungan kelurga dan rekan tani, dukungan sosial yang tinggi memungkinkan seseorang individu lebih terbuka terhadap informasi.

\section{Hubungan Tingkat Dukungan Ekonomi ( $\left.\mathrm{X}_{5}\right)$ dengan Keputusan Petani (Y)}

Berdasarkan Tabel 1 dapat di lihat bahwa nilai koefisien korelasi antara variabel tingkat dukungan ekonomi sebesar 0,654 dengan tanda positif dan signifikan pada taraf kepercayaan 95\%. Hal tersebut menunjukan bahwa tingkat dukungan ekonomi memiliki hubungan yang positif serta tingkat hubungan yang kuat dengan keputusan petani, dimana koefisen variabel tingkat dukungan sosial berada pada interval $0,60-0,97$ sesuai dengan interpretasi kuatnya hubungan korelasi menurut Sugiyono (2014)

Mardikanto, et al., (1996) menyampaikan bahwa kegiatan pertanian tidak dapat lepas dari kekuatan ekonomi yang berkembang di sekitar masyarakatnya. Kekuatan ekonomi tersebut meliputi: 1) tersedianya dana atau kredit usahatani, 2) tersedianya sarana produksi dan peralatan usahatani, 3) perkembangan teknologi pengolahan hasil, 4) pemasaran hasil. 


\section{KESIMPULAN DAN SARAN}

\section{Kesimpulan}

1. Tingkat pendidikan tidak memiliki hubungan yang signifikan dengan keputusan petani menanam padi varietas ciherang.

2. Lama berusaha tani tidak memiliki hubungan yang signifikan dengan keputusan petani menanam padi varietas Ciherang.

3. Persepsi petani terhadap padi varietas Ciherang memiliki hubungan yang positif dan signifikan dengan keputusan petani menanam padi varietas Ciherang dengan nilai koefisien korelasi sebesar 0,531.

4. Tingkat dukungan sosial memiliki hubungan yang positif dan signifikan dengan keputusan petani menanam padi varietas Ciherang dengan nilai koefisien korelasi sebesar 0,689

5. Tingkat dukungan ekonomi memiliki hubungan yang positif dan signifikan, dengan keputusan petani menanam padi varietas Ciherang dengan nilai koefisien korelasi sebesar 0,654.

\section{Saran}

Dari hasil penelitian yang dilakukan di Desa Rogomulyo Kecamatan Kaliwungu Kabupaten Semarang, maka saran yang diberikan:

1. Tingkat pendidikan dan lama berusaha tani tidak menunjukan hasil yang signifikan, maka sebaiknya untuk penelitian selanjutnya diberikan sosialisasi untuk petani yang sudah lanjut usia.

2. Penelitian selanjutnya dapat memasukkan variabel saluran antar pribadi salah satu yang dapat mengetahui keputusan petani menanam padi varietas Ciherang.

3. Penelitian selanjutnya sebaiknya adanya peran pemerintah, penyuluh lapangan, kelompok tani, untuk meningkatkan dukungan sosial/ekonomi dengan keputusan petani menanam varietas padi.

\section{DAFTAR PUSTAKA}

Mardikanto. 1996. Penyuluhan Pembangunan Kehutanan. Pusat Penyuluhan Kehutanan Departemen Kehutanan RI bekerjasama dengan Fakultas Pertanian Universitas Sebelas Maret (UNS). Jakarta. 
Jayanti, M. 2011. Faktor-Faktor yang Mempengaruhi Keputusan Petani Padi Sawah Menggunakan Benih Menurut Sumber Benih. Skripsi Program Studi Agribisnis. Fakultas Pertanian Universitas Sumatera Utara. Medan.

Rogers, E.M. 1983. Diffusion of Innovations. Ed.3. .[Internet]. [diunduh 22 Feb 2018]. New York (US): Macmillan Publishing. Tersedia pada: http://teddykw2.files.Wordpress. com/2012/07/everentt-m-rogersdiffusion-of-inovations.pdf.

Roswita, R. 2003. Tahapan proses keputusan adopsi inovasi pengendalian hama dan penyakit tanaman dengan agen hayati (kasus petani sayuran di Kecamatan Banuhampu dan Sungai Puar Kabupaten Agam Sumatera). Tesis .[Internet]. [diunduh 22 Feb 2018]. Bogor (ID): IPB. Tersedia Pada: http://repository.ipb.ac.id/bitstre am/handle/123456789/7703rro.p $\mathrm{df}$ ? sequence $=4 \&$ is Allowed $=\mathrm{y}$.

Rizka, F.F. 2015. Hubungan karakteristik inovasi budidaya padi metode SRI (system rice intensification) dengan pengambilan keputusan adopsi oleh petani [skripsi]. Bogor (ID): IPB.

Susanti. 2008. Faktor-faktor yang mempengaruhi pengambilan keputusan petani dalam penerapan pertanian padi organik di Desa Sukorejo, Kecamatan Sambirejo, Kabupaten Sragen. J. Agritexts 24: 1-14. [Internet]. [Diunduh pada 22 Feb 2018]. Solo (ID): UNS. Tersedia pada: http://fp.uns.ac.id/jurnal/down load.php?file=Agritex-4.pdf.

Sugiyono. 2011. Metode Penelitian Kuantitatif, Kualitatif, dan R\&D. Bandung: Alfabeta.

Sugiyono. 2014. Metode Penelitian Kuantitatif, Kualitatif dan R\&D. Bandung: Alfabeta.

Siregar, S. 2013. Statistik Parametrik untuk Penelitian Kuantitatif. Jakarta. PT. Bumi Aksara. 387 halaman.

Thoha. 1996. Perilaku Organisasi: Konsep Dasar dan Aplikasinya. Jakarta: Raja Grafindo Perkasa. 